\title{
THE USE OF LITERACY-INSTRUCTIONAL CATEGORY TO IMPROVE STUDENTS' READING COMPREHENSION
}

\author{
Setiarini \\ IAIN Salatiga \\ Setiarini.setia@gmail.com
}

\begin{abstract}
This investigation examined the use of Literacy-Instructional Category on students' reading comprehension. Particularly, there are two objectives of the study. The first is to explore the students' writing improvement when they engaged in the first cycle of reading activities by employing literacy instructional categories. The second is to explore the students' reading comprehension by using instructional categories. Thirty students from English Department of IAIN Salatiga participated in the study and they were in the third semester. A classroom action research was employed to answer the research problems. Three cycles were done to complete this action research. Based on the score result gathered from the cycles, the students' reading comprehension improved. The student's scores were not more than sixty because they did not understand intensively rereading activities in cycle one. But students' score increased in cycle two and cycle three. In cycle three, rereading activities followed transformed practice (critical framing) lead the better improvement in their reading comprehension.
\end{abstract}

Keywords: Literacy-Instructional Category, Reading Comprehension 


\section{Introduction}

As one of the compulsory activity, reading becomes the basic need for people to enrich the knowledge. In part of building academic professionalism, students need reading activity of the text. Understanding text written in a foreign language is a significance challenge for most university students. As language learners, they must learn to navigate through unfamiliar vocabulary, grammar, and cultural references. In fact, foreign language teacher then has the challenge to serve the appropriate guidance and support to the learners.

Here, Chiu (2015) stated that the teacher plays as the part for fostering learner to read academic text. In fact, there are two main components that learner must master well in reading various kind of academic text. They are the rapid word recognition and the text comprehension. However, those two components are not easy to be gained by foreign language learners except they contribute by studying hard. Then the sentence that seemingly appropriate to be asserted is 'the more frequency of students in reading, the more students understand the text comprehensively'.

Discussing reading means that there is an activity followed or what is said as writing. Reading and writing is the integrated process that is required for the students' literacy. Language learner in academic setting is intended to read complex texts. The basic principle of literacy based program is that students need controlled task, not controlled text. Concerning the appropriate instruction, it has to be followed by the proper order of controlled classroom task.

Traditionally, the activity of reading, talking and writing are relatively distinct phases of a linear instructional sequence. The example of controlled task is when the students prepare for class by reading a text and they speak what they have read. Since speaking what students have read is not enough, to control their speaking teacher can instruct them to write down a summary. Reading, speaking, and writing phase are not normally followed without rereading activities especially by foreign language learner. That is why re-reading activity is the suggestive activity. It acts as the prominent aspect and the supportive activity that leads the better achievement 
in the last phase or writing phase. Re-reading activity means that the reader repeatedly read the same text to understand the text discourse (Kern: 2000).

What should be proposed last is the back movement to three phase activities or reading, talking and writing to be connected with re-reading. Re-reading activities when it is only completed by speaking activity does not gain the literacy based program. What students talked about the text to be written by them will gain the literacy program. The literacy program helps them to control their idea by summary writing. This reasearch is aimed at answering the question How is the students' reading comprehension achievements taught using literacy-instructional category?

\section{Background Literature}

\section{Literacy in Language Education}

Language awareness in education is crucial. Lier (1995) as quoted by Umami (2008: 5) stated that language is crucial when language is seen as a goal of language arts, literacy, and other language. Language acts as the vehicle that meaningful in learning particularly in lecturing, conversation, reading, thinking and so on. In fact, literacy later concerns with any efforts allowing people to be well informed and knowledgeable. Umami (2008: 7) later asserted the conclusion of literacy by quoting the Perez statement. Literacy is a multifaceted manifestation of reading, writing, and thinking through which meaning is created within socio-cultural context.

Norton (2010: 10) said on his research conclusion, that literacy is not only about reading and writing. Literacy is also about the text and the reader, student and teacher, classroom and community, in local, regional, and international areas. That is why if learner engage in literacy practice, they also engage in acts of identity. It means that learners identify the sense of making meaning. At the final point is that Guthrie statement. He (2004: 26) claimed that at the present, English teachers live in the threatening times. In addition, especially in part of engaging students in literacy activities, teachers have to take their density to innovate the literacy activities based on the curriculum standards. 


\section{Reading as a Road to Writing}

Beene and Kopple (2004: 1) claimed that serious reading, reflecting and writing activities as well as employing serious effort and commitment has to be applied by the students and aspiring professional. Not only students or aspiring professional, as the readers, they are good reader when they are able to convey their own perspective. Readers whatever their response in reading, the responses are their reaction. Transferring the reading process by the reader's own writing leads the reader to control their own confidence in writing process.

One of the student's exercises as proposed by Beene and Kopple (2004: 4) entitled 'The- Postman-Paglia Dialogue' helps the students to monitor their initial reactions. They lead the students to complete the strategies in reading and critical thinking as well as writing. 'The Postman-Paglia Dialogue' is the conversation followed by the fundamental literary references. Due to the informal dialogue, social exchanged occurred. Paglia and the postman spoke without detailed explanation and some evidence slightly flippant. The addition fact is that between Paglia and the postman has not the same background, so that different perspective on the issues is developed.

The student's exercise to read and sum up by writing text Paglia and postman dialogue fosters the students to achieve the purpose of reading by reasoning carefully, analyzing closely, recognizing the conflicting point of issues and improving communicative skills. Those activities can be seen appropriately by the students' process in writing. In short reading dynamically used by writing leads the students to beyond the current barriers that they know becomes into new thought and new ways in creating their views.

Analyzing closely in reading is looking for meaning in the word and sentences. That activity is executed as well as discovering meaning between the lines and in what initially seems insignificant. The reader evaluates on how a text parts create a whole. In addition, rereading is fundamental to foster the reader to analyze closely. As rereading process occurs, questions about the text and the writer are raising. What make the reader agree and disagree is written down. 
Analyzing by rereading can be connected to the summarizing activity too. One of the summarizing activities is finding the main idea. Rereading to find main idea as asserted by Beene and Kopple (2004: 21 ) is followed by five strategies which will be mentioned in the summarization section.

\section{Four Curricular Components on Literacy}

As New London Group (1996) quoted by Kern (2000: 133) stated that there are four curricular components which play as the fundamental parts in addressing the learner's literacy need. To achieve the aims of realizing discourse from texts, considering a variety of activities based on the four curricular components is necessary included.

DRTA

reader's theatre reading journals focusing on relationships textual comparison critical focus questions summary writing Translation dialogic transformations

\begin{tabular}{|c|c|c|c|}
\hline $\begin{array}{l}\text { situated } \\
\text { practice }\end{array}$ & $\begin{array}{c}\text { overt } \\
\text { instruc- } \\
\text { tion }\end{array}$ & $\begin{array}{l}\text { critical } \\
\text { fram- } \\
\text { ing }\end{array}$ & $\begin{array}{l}\text { trans- } \\
\text { formed } \\
\text { practice }\end{array}$ \\
\hline $\mathrm{V}$ & $(\mathrm{v})$ & (v) & \\
\hline $\mathrm{V}$ & & (v) & $\mathrm{V}$ \\
\hline $\mathrm{V}$ & & (v) & \\
\hline $\mathrm{V}$ & V & (v) & (v) \\
\hline $\mathrm{V}$ & $\mathrm{V}$ & $\mathrm{V}$ & \\
\hline (v) & (v) & $\mathrm{V}$ & (v) \\
\hline (v) & $\mathrm{V}$ & $\mathrm{V}$ & $\mathrm{V}$ \\
\hline (v) & & (v) & $\mathrm{V}$ \\
\hline (v) & (v) & (v) & $\mathrm{V}$ \\
\hline
\end{tabular}

Figure. 1.1: Summary of Reading Activities based on Literacy-Instructional Category as Adapted by Kern (2000: 160)

\section{a. Situated practice}

Situated practice in teaching reading has to be focused on the 'immersion' activity. It is an act of finding the meaning design during reading. The focus of situated practice in curricular components is to communicate 'at the present' based on the lives, experiences, and spontaneous expression of thought, opinion and feelings. Three activities which are appropriate in 
the situated practice in teaching reading are direct reading, reader's theater, and reading journal.

The first activity is direct reading. Kern (2000: 135) wrote that direct reading is developed by Stauffer (1969). Stauffer (1969) claimed that Direct Reading Thinking Activity (DRTA) encourages readers to read purposively, to make predictions and inferences during reading, and to evaluate the appropriateness between information in the text and their own mental representations of the text. The teacher's role in direct reading is stimulating the learner to predict, read, and thinking by sorting the prominent points of the text. DRTA leads the reader into the arena of social interaction.

The second activity is reader's theater. On the activity of making theater, scripting process executed by the readers after read particular text fosters them to be creative in redesigning the script. Through scripting the readers perform the script to show their interpretation and ideas toward a text. Oral discussion at the level small group when the learner prepares the script and oral discussion in the class after performance automatically built the stage of critical framing. The last activity is reading journal.

\section{b. Overt Instruction}

It focuses learners' attention explicitly on Available Designs and their use. It involves creating scaffold learning, not just drills and memorization. Furthermore it introduces an element of conscious control as well as a vocabulary to allow students to talk about the meaning design process.

Receiving direct assistance in the complexities of reading the text has to be served by the teacher in the overt instruction section. According to Kern (2000: 144), two categories of activities are offered in the area of overt instruction. The first is the activity which focuses on the language relationship. The other activity is the activity held on teaching genres.

Teaching focused on language relationship in reading is divided into six segments. First is the focusing in the word relationships particularly in the study of vocabulary. Second activity 
is the activity of identifying the syntactic relationship. The complex text read by the learners consists of structured parts that students have to be mastered it well. Learners are instructed as the editor or analyst a difficult passage in order they are able to rewrite the text with their own character.

Activity three is focused on the overt instruction in discourse structure relationship. There are two way for teacher to develop the learner's understanding of discourse structure of the text. They are the present plentiful examples of signaling cues embedded in texts, and the training for learner to recognize the signaling cues as they read. Teacher questions during class readings of texts are keys in focusing student's attention on other dimensions of discourse organization as well.

The fourth activity is focusing on cohesion relationships Drawing lines to identify relations of conference of the passage that is done by learner is the aim of understanding the cohesion relationship in a text. The fifth is the activity focused on the coherence relationships via mapping. On the mapping process the learner is permitted to represents complex networks of the text elements relationship. Teacher can stimulate the learner in mapping activity by designing map in pairs or individually and then discuss the map. The last is the activity concentrated on the text reader relationships. Paraphrasing of a text is appropriate to command in the overt instruction.

Leaving the teaching activity focused on the language relationship in reading, teaching genres particularly in comparing text is included in overt instruction part. Working with multiple texts is principal in teaching genre. It is asserted as the reason because the students are needed to identify what the common exists in a group of the texts. In terms of design model, the activity is meant not only to increase student's awareness of formal features of a genre, but also to help them understand how that genre connects to purposes, audience, social roles, and social practices in both communicative and larger socio-cultural context. 
c. Critical Framing

Learning when it is targeted at critical framing accompanied by absorbing information to analyze and evaluate what the reader's read. Contrastively with what the focus gained on situated practice, Kern (2000: 133) wrote that critical framing is followed by the how the reader thinks the 'step back' and the 'future' communication. There are two reflective activities in the process of critical framing. They are critical focus question and summary writing.

On the teaching activity of critical focus question, stimulating students by question is needed. Questions allow the students to see how the discourse of the text is applied. Critical focus questions support the process of reflection in reading process.

On the other hand, critical framing is not only tied with the activity of questioning but also included by summarizing process. Summarizing can be applied by conducting the discussion activity, analysis and direct comparison of the reader's perspectives.

\section{d. Transformed Practice}

Learner on the activity of transforming is instructed to redesign texts through summarization, rewriting, or translation. Critical question and summary writing are also included in the activity of transforming. It is aimed for learner to redesign and reformulate the text. Automatically, all writing based on reading is an instance of transformed practice.

"Rather than simply a 'check' of mastery of lexical and syntactic structures, translation can, like summaries, be used as a way of comparing and contrasting parallel 'reading' of text." (Kern (2000: 158) The quotes above mentioned that translation is not assumed as ineffective activity of transformed practice. The other activity such as dialogic transformation is permitted in transforming activity. In the section of dialogic transformation, learner is commanded to make an expository passage into writer and reader dialogue. 
The Use of Literacy-Instructional Category ...

e. Reading Journal

One of the best ways to make the students immersed in reading outside of class is to read independently. The students are free to read the texts that raise their interest, such as magazines, books, comics or another kind of text. On the academic situation, journal is one of the appropriate texts to read by students. Kern (2000: 143) stated there are five activities in reading journal based on the literacy need. The five activities are citing the full reference of the text, indicating the reason of choosing the text, summarizing the text, expressing the response of the text and reflecting the process of reading the text.

The sensitivity of reading is not only tied into the text details, but also the process of the reader in reading the text. Teacher in the student's reading activity is able to discuss strategies that are commonly presented in the student's report, such as rereading, translating, and inferring from context and so forth. Initial reading (situated practice) and the reflection (critical framing) can guide to follow up lessons focused on the overt instruction. In the case of reading journal the focus is on the available design (vocabulary, genres, style, procedural knowledge, cultural knowledge) as they are applied in communicative practice.

\section{f. Summary Writing}

Reading for academic purposes is commonly combined with writing activities such as note-taking, answering post-reading questions, summarizing and writing response papers. Chiu (2015: 1) proposed that summarization activity has to be included by the activities of identifying main idea, omitting the unimportant information, and recreating ideas obtained by reading original text. Summarization later included as one of transforming activity in reading.

As quoted by Kern (2000: 157), Hidi et al (1986) proposed that summary also used as critical framing activity involving discussion, analysis, and direct comparison of reader's interpretation. Because summary writing included by re-conceptualization and transformation, it can involve substantial cognitive load 
and can therefore be a difficult task for many students. Chiu (2015: 2) argued one addition that summarization has attracted the most research attention. It is happen because summarization assumed to be strategy instruction that support learners to identify macropropositions. Identifying the macroposition of a text pushes the process of understanding the text did by learner. When summarizing a text, learners engage in a process that involve identifying the main ideas in a passage, distinguishing major and minor details, and restating the main ideas with the goal of expressing the ideas of the passage.

Carter (1986) as quoted by Kern (2000: 158) pointed out that summarizing activity lies on the existence of three reasons. The three reasons are leads to the purpose that the reader has to be achieved. The starting reason is that summarization forces the reader to take the prominence on the text and to employ the interpreting activity. The second reason is that summarization stimulates the reader to share the expression by deleting, structuring, and reshaping ideas by transforming activity. The last reason is that summarization is aimed for the reader to present the act of 'realization'. It is an act of taking the value of the text.

Taking the value of the text makes the rereading activity is fundamental to foster the reader to analyze closely. Since reading once is not gaining the comprehensive analyzing, foreign language learner need re-reading to foster their understanding. In literacy need, to control the task, the teacher is the person who plays in fostering learners to gain their understanding of the text. As rereading process occurs, questions about the text and the writer are raising. What make the reader agree and disagree is written down. Analyzing by rereading can be connected to the summarizing activity too. One of the summarizing activities is finding the main idea.

Rereading is related to the summarizing activity. One of the summarizing activities is finding the main idea. Rereading particularly in finding the main idea is followed by five strategies. As asserted by Beene and Kopple (2004: 21) the five strategies are: 1.) Identifying the writer's thesis statement (the sentences 
which contains the purpose statement), 2.) Identifying the topic sentence of each paragraph, 3.) finding the general points or ideas of a paragraph, 4.) determining whether specific details in a text, confirm, explain, or contradict toward the topic sentence; and 5.) determining whether individual topic sentence confirm, explain, or contradict toward the thesis statement.

The passage below presents the rubrics for writing and the rubric for assessing student writing particularly in summary section.

\section{Methods}

This study is conducted by using classroom action research design. Action research design is related to the ideas of 'reflective practice' and 'the teacher as researcher'. It involves taking a selfreflective, critical, and systematic approach to exploring your own teaching contexts. One of the basic goals of action research is to identify a 'problematic' situation or issue that the participants consider worth looking into more deeply and systematically. The term problematic does not mean that the teacher is not competent. The point is that, as teachers, we often see gaps between what is actually happening in our teaching situation and what we would ideally like to see happening. Thus, the central idea of the action part of action research is to intervene in a deliberate way in the problematic situation in order to bring about changes and better improvements in practice. (Burn, 2010: 2)

According to Kemmis and McTaggart (1988) as written by Burn (2010: 8), action research typically followed by four broad phases of research cycle. The first cycle may become a continuing, or iterative, spiral of cycles which recur until the action researcher has achieved a satisfactory outcome and feels it is time to stop.

The first step of Action Research is the planning. In this phase the researcher identify a problem or issue and develop a plan of action in order to bring about improvements in a specific area of the research context. This is a forward-looking phase where the researcher considers: what kind of investigation is possible within the realities and constraints of your teaching situation; and what poten- 
tial improvements which are possible.

The second step of Action Research is the Action. The plan is a carefully considered one which involves some deliberate interventions into your teaching situation that you put into action over an agreed period of time. The interventions are 'critically informed' as you question your assumptions about the current situation and plan new and alternative ways of doing things.

The third phase of action research is the observation. This phase involves the researcher to observe systematically the effects of the action and documenting the context, actions and opinions of those involved. It is a data collection phase where the researcher should use 'open-eyed' and 'open-minded' tools to collect information about what is happening.

The last phase of action research is the reflection. At this point, the researcher reflects, evaluates and describes the effects of the action in order to make sense of what has happened and what is the issue. The researcher here, decide to do further cycles of Action Research which are described on the following passages.

What is action research? 9

CYCLE 1

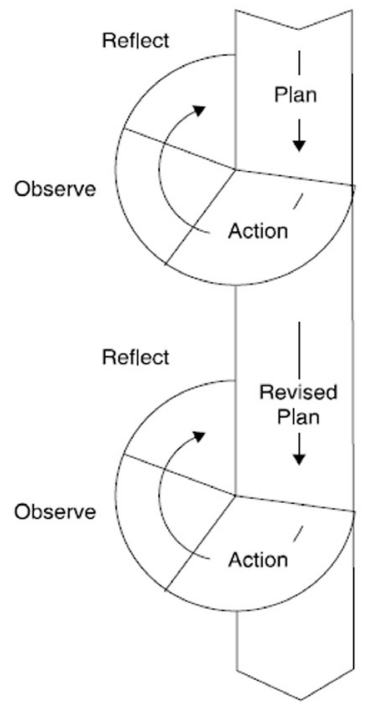

Figure 1.1. Cyclical Action Research Model based on Kemmis and Mc'Taggart (1988) as cited by Burns (2010: 8) 
The core of this research is to answer the assumption that by re-reading activity, the student's mastery in writing is improved. To achieve the purpose of the student's improvement in writing skill, procedure mentioned in the literacy perspective is used. Completing the re-reading activity, three stages called as 'the three cycle of classroom action research' are applied. Cycle one is when the students engage in the situated practice of reading. Cycle two is when the students contribute in the re-reading activity as active as effective by employing overt instruction activity. The last part called as cycle three is when the students presented activity of critical framing and transformed practice after re-read the text.

The following table is the rubrics used as a guide to give score on students writing summary.

\section{Rubric for Assessing Student Writing: Summary}

$\begin{array}{ll}\text { Name } & : \\ \text { Class } & : \\ \text { Date } & \text { : }\end{array}$

\begin{tabular}{|c|c|}
\hline $\begin{array}{l}\text { Focus or Organization } \\
\text { a. The piece fulfills its purpose by retelling } \\
\text { the main idea and important details. } \\
\text { b. The piece does not include minor details or } \\
\text { unrelated information. } \\
\text { c. The piece is written in writer's own words. } \\
\text { d. The piece is arranged in an appropriate and } \\
\text { clear order. }\end{array}$ & Comments: \\
\hline $\begin{array}{l}\text { Elaboration or Support or Style } \\
\text { a. The opening or closing sentence clearly } \\
\text { states the main idea. } \\
\text { b. All of the important details that support } \\
\text { the main idea are included. } \\
\text { c. Transition words are used effectively. }\end{array}$ & Comments \\
\hline
\end{tabular}




\section{Grammar, Usage, and Mechanics}

\section{Comments}

a. The writing is free of misspellings, and words are capitalized correctly.

b. Sentences are punctuated correctly, and the piece is free of fragments and run-ons.

c. Standard English usage is employed.

d. The paper is neat, legible, and presented in an appropriate format.

Score: 130

\section{Engagement in the Writing Process Comments}

- The student made a prewriting plan

- The student discussed the draft with a partner or small group

- The students contributed questions and suggestions to other writers

- The students revised the draft

- The students proofread the final draft

Overall Score / 100

\section{Findings}

The subject of this research is the thirty students who take part in Reading 3 Class.

\section{Table 1.1. The Students' Score Achieved in Three Cycles of Classroom Action Research}

\begin{tabular}{|c|l|c|c|c|}
\hline No & \multicolumn{1}{|c|}{ Name } & $\begin{array}{c}\text { Score } \\
\text { I }\end{array}$ & $\begin{array}{c}\text { Score } \\
\text { II }\end{array}$ & $\begin{array}{c}\text { Score } \\
\text { III }\end{array}$ \\
\hline 1 & Alfiatu Rohmah & 0 & 0 & 0 \\
\hline 2 & Willy Ramadhan Putra & 0 & 0 & 0 \\
\hline 3 & Yurvistasari & 50 & 72 & 74 \\
\hline 4 & Uswatun Hasanah & 50 & 77 & 78 \\
\hline 5 & Nastiti Arif Fadhilah Aina Mardziyah & 50 & 78 & 79 \\
\hline 6 & Novi santika Dewi & 50 & 75 & 0 \\
\hline 7 & Hayyu Nafiatul Fauziyah & 50 & 77 & 84 \\
\hline
\end{tabular}


The Use of Literacy-Instructional Category ...

\begin{tabular}{|c|l|c|c|c|}
\hline 8 & Mir'atus Sa'adah & 50 & 65 & 0 \\
\hline 9 & Lina Nurul Halimah & 50 & 78 & 80 \\
\hline 10 & Ja'far Abdu Latief & 30 & 60 & 0 \\
\hline 11 & Venti Fajarini & 50 & 0 & 70 \\
\hline 12 & Nur Hayati & 50 & 72 & 74 \\
\hline 13 & Wahyu Tri Lestari & 50 & 0 & 80 \\
\hline 14 & Dewi Hindun Yuliana & 40 & 65 & 80 \\
\hline 15 & Aina Maghfiroh & 30 & 0 & 72 \\
\hline 16 & Laila Khusnul Himmah & 0 & 0 & 70 \\
\hline 17 & Evi Nur latifa & 50 & 70 & 0 \\
\hline 18 & Ela Rosita Dewi & 0 & 0 & 80 \\
\hline 19 & Muhammad Iqbal fauzi & 30 & 60 & 75 \\
\hline 20 & Zalsa Febrina Syabilla & 50 & 74 & 80 \\
\hline 21 & Moh. Adib Fathurrahman & 50 & 78 & 70 \\
\hline 22 & Erlina Hidayanti & 50 & 76 & 80 \\
\hline 23 & Ririn Nur Halifah & 50 & 75 & 80 \\
\hline 24 & Elsa Putri Novita Sari & 50 & 72 & 86 \\
\hline 25 & Ayu Wulandari & 50 & 70 & 80 \\
\hline 26 & Nurma Dwi Airisa & 50 & 75 & 85 \\
\hline 27 & Leila Khairani & 50 & 71 & 80 \\
\hline 28 & Hakimee Samalee & 60 & 78 & 85 \\
\hline 29 & Ummul Iman Yusuf & 50 & 76 & 77 \\
\hline 30 & Surainee Tohyeng & 50 & 70 & 68 \\
\hline & & & \\
\hline
\end{tabular}

According to the four curricular components in teaching reading activity based on the literacy need, there are three cycles employed in the activities of re-reading in supporting students writing skills.

The cycle one is the employing situated practice by reading the text of 'Paglia and Postman Dialogue' as the need of literacy. Instructed by the teacher, the first activity of reading the text was done by thirty students. The second activity held in the cycle one was the students re-wrote a text. They wrote as well as finished the process of looking carefully at font, words, sentences, and text. After they wrote, the students were instructed to conclude what was said 
by Paglia and Postman. They finished the instruction by writing in summary for each turn of dialogue.

Still held in cycle one, after they had completed the summary per turn, they had to find the essential and the important points asserted in the dialogue. The important points were written by the students into the summary of the overall dialogue of 'Paglia and the postman'. What have to be drawn up from the table 1.1 on the score I column is that that cycle one or situated practice stage has to be completed by other two cycles. The remaining two cycles completed by the students is needed to increase the student's score of re-reading activities based on literacy perspective.

Cycle two which was conducted by the teacher was the revision process. The revision process was based on the literacy instructional category particularly in overt instruction. The first was the activity which focused on the language relationship. The students received the evaluation on their presentation which is held in the cycle one and they instructed to re-read the 'Paglia and the postman dialogue'. They instructed to evaluate their previous summary.

By receiving what should be evaluated particularly on the evaluating language relationship, students automatically revised the previous summary by teacher instruction. They revised summary for each turn of dialogue. After they have completed in revising the summary for each turn dialogue, they revised the essential and the important points asserted in the dialogue. The important points were called as the summary of the overall dialogue of 'Paglia and the postman'. In the cycle two, again, they wrote the summary of overall dialogue and revised the summary per turn of the dialogue. The score II mentioned in the table 1.1 gives the result on the student's development stage in overt instruction stage in re-reading activity.

It seems incomplete when teacher leave the remaining two categories of literacy instructional categories. They are critical framing and transformed activity which were used in the cycle three. On the cycle three, the teacher proposed the assertion of re-reading process to the students. The students were commanded to write the difference between television and book. It was not presented explicitly, but became the discussed matter on the dialogue of 'Paglia and the 
postman'.

On the cycle three, the purpose of student's critical framing was shaped. Critical framing which is the third stage of literacy instructional category. After they re-read the dialogue of "Paglia and the postman dialogue', they interpreted what on their mind about the dialogue. The students wrote their interpretations and responses of television and book. Their interpretation is presented by the students in summary writing. Their writing summaries were proven their obvious effort on critical framing stage. The critical framing which was shaped by the students as quoted by Kern (2000) in the previous section leaded to the noticeable activity of transformed practice. Students summarize their idea by writing paragraph why they chose television or book. It is based on the assertion that all writing based on reading is an instance of transformed practice. The table 1.1 particularly on the column score III provides the results of the cycle three. The cycle three as the completion of re-reading activities gives the improvement result in summary writing which students done by re-reading activity.

\section{Conclusion}

The students reading comprehension improvement can be seen when they read the text in the reading activities in the cycle one which also can be drawn up by the noticeable score of the first summary writing in the cycle one. On the cycle one execution or situated practice stage, the students' score improved. Their reading comprehension in cycle one is not better than when they engaged in reading activities particularly in cycle two and cycle three. It is shown in the score I mentioned in the table 1.1. Generally, the student's score is not more than sixty.

When the students engaged in rereading activities, their reading comprehension improved. Students engaging the cycle two show their increasing score in writing. They achieved the better improvement in the cycle two than the first cycle. The significant improvement shown after the students contributed in rereading activities in cycle three. Followed by complete literacy instructional category and rereading activities, the students generally improve on their 
reading comprehension. Therefore, the student's writing improvement when they engaged in rereading activities are better than when engaged in general reading activities. It is shown in the score II and III mentioned in the table 1.1. In general, the student's score is more than sixty.

Here the teacher provides an opportunity for dynamic assessment such as by giving feedback to students to inform student's development and improvement of their literacy activities. 


\section{REFERENCES}

Been, Lynn and William Vande Kopple. 2004. The Riverside Handbook. Boston: Library of Congress Catalogue.

Chiu, Chia Hui. 2015. Enhancing Reading Comprehension and Summarization Abilities of EFL Learners through Online Summarization Practice. Available on The Journal of Language Teaching and Learning page: 79-95

Guthrie, John T. 2004. Teaching for Literacy Engagement. Retrieved from jlr.sagepub.com: Journal of Literacy Research

Kern, Richard. 2000. Literacy and Language Teaching. Oxford: Oxford University Press.

Norton, Bonny. 2010. Identity, Literacy and English-Language Teaching. Canada: TESL Canada Journal. Vol: 28.

Burns, Anne. (2010). Doing Action Research in English Language Teaching: A Guide for Practitioners. New York: Routledge.

Umami, Mashlihatul. Rethinking Language Education in Indonesia. Salatiga: Published in the journal of English Department of Education Faculty State Islamic Studies Institute (STAIN) Salatiga. 
